\title{
Emerging Trends in Foreign Trade of India -A Glimpse into the Post Globalised Economy
}

\author{
Lakshmi. P* and M. S. Raju**
}

\begin{abstract}
The World Bank reports that India will emerge as the top economies of the world by 2016 ahead of China.(World Bank, 2015). With a population of 1.295 billion, the GDP of India is \$ 2.649 trillion at market prices. According to IMF World Economic outlook, April 2015, India ranks seventh globally in terms of GDP and expected to grow at $7.5 \%$ in 2016. (IMF, 2015). Trading becomes more organized and productive as civilization progressed around the world. Technology and innovation are being increasingly considered by economists as an important factor of production and competitiveness in a knowledge driven economy in globalizing world. This paper analyses the trends in Indian exports based on past 15 years, data covering the period 1999-2000 to 2015-16 adopting the projected value of export from India for the next 10 years from 2016-17 to 2025-26.The results showed the value of exports will increase from Rs.1949745.95 Crores in 2016-17 to Rs. 3039414.07 crores in 2025-26.
\end{abstract}

Keywords-Foreign Trade, Trade deficit , Transfer of Technology , Liberalization

\section{INTRODUCTION}

$\mathrm{F}$ OREIGN Trade involves different currencies of different countries and is regulated by laws, rules and regulations of the concerned countries. Foreign trade acts an engine of growth in the concerned economies. In a globalizing world which is driven by knowledge, technology and innovation are considered as important factors boosting the competitiveness. As a result of globalization, the information technology in India has made rapid strides, especially in software industry. Many Indian companies have made large international acquisitions and become global companies. For example, Tata Steel acquired Corus in a multi-billion-dollar deal. Bharati airtel made a large telecom takeover by acquiring the African business of Zain Telecom. Tata Motors took the bold step by acquiring Jaguar and Land Rover. The acquisition of Jaguar and Land Rover has proved to be very profitable for Tata Motors. This paper analyses the growth of Indian foreign trade after independence and post globalised scenario. This paper also tries to find out the recent trends in the Indian foreign trade. A perusal of the performance of the global economy, since the financial crisis in 2008, indicates that while developed economies have been facing stagnant GDP growth

Lakshmi. P, School of Management and Entrepreneurship. Kerala University of Fisheries and Ocean Studies, Panangad, Kochi, Kerala

M. S. Raju , School of Management and Entrepreneurship. Kerala University of Fisheries and Ocean Studies, Panangad, Kochi, Kerala. rates, Emerging Market and Developing Economies (EMDEs) have seen recovery with divergent growth. In the current global economic scenario, there are elements of risk, challenges and market volatility. This volatility is reflected in the impact of weakening commodity prices and difficult financial conditions, especially of oil exporters. As per the World Economic Outlook update of January, 2016, global growth, currently estimated at 3.1 percent in 2015 , is projected to be 3.4 percent in 2016 and 3.6 percent in 2017. In IMF's World Economic Outlook (January 19, 2016) India and the rest of emerging Asia are generally projected to continue growing at a robust pace. As per Economic Survey 2015-16, the projected growth rate of GDP for the year 2015-16 is likely to be between $7 \%$ to $7.6 \%$. There is unusual volatility in the international economic environment. Markets have begun to swing on fears that the global recovery may be faltering, while risks of extreme events are rising. Amidst this gloomy landscape, India stands out as a haven of stability and an settlement of opportunity. Its macro-economy is stable, founded on the government's commitment to fiscal consolidation and low inflation. Its economic growth is amongst the highest in the world, helped by a reorientation of government spending toward needed public infrastructure. These achievements are remarkable not least because they have been accomplished in the face of global headwinds and a second successive season of poor rainfall. As per the current rankings for the year 2014, India is the 19th largest exporter (with a share of 1.7\%) and 12th largest importer (with a share of $2.4 \%$ ) of merchandise trade in the world. In Commercial Services Exports, India is the 8th largest exporter in 2014 (with a share of $3.2 \%$ ). In imports of commercial services India ranks 10th (with a share of 2. 6\%).India's merchandise exports for the year 2014-15 stood at US \$ 310.33 billion as against US \$ 314.40 billion in 2013-14 registering a negative growth of $1.29 \%$, while imports in $2014-15$ came down to US \$ 448.03 billion from US \$ 450.20 billion in 2013-14 registering a negative growth of $0.48 \%$. The Trade deficit in 2014-15stood at US \$ 137.69 billion.

Exports during January, 2016 were valued at US\$ 21.1 billion which was 13.60 per cent lower in Dollar terms than the level of US\$ 24.4 billion during January, 2015. Cumulative value of exports for the period April-January 2015-16 was US\$ 217.7 billion as against US\$ 264.3 billion registering a negative growth of 17.65 per cent in Dollar terms over the same period last year. Non-petroleum exports in January 2016 
are valued at US\$ 19.1 billion against US\$ 21.4 billion in January 2015 , a reduction of $10.55 \%$. Non-petroleum exports during April to January 2016 are valued at US\$192.4 billion as compared to US\$212.7 billion for the corresponding period in 2015, a reduction of 9.6\%.Oil imports during January, 2016 were valued at US $\$ 5.0$ billion which was 39.01 per cent lower than oil imports valued at US\$ 8.2 billion in the corresponding period last year. Oil imports during April-January, 2015-16 were valued (Department of commerce, annual report,201516). This paper also gives a brief idea about recent trends and emerging business models in foreign trade of India after globalization.

\section{RECENT TRENDS IN ForeIgN TRADE OF INDIA AFTER GLOBALIZATION}

There is considerable resistance to the relaxation of controls on foreign Trade from the vested interests as well as from those who are wedded to the blinkered pattern of development which was the guiding spirit of the Indian economy in the past. (Mishra K Tushar, 1992) . Globalization otherwise known as an economic integration resulted in the paradigm shift in the world trade. Globalization implies widening and deepening assimilation with the globe ie with people and process abroad. As a result of globalization the smaller, emerging economies got much market access and it resulted in a new business frame work characterised by openness, adaptiveness and responsiveness. The most important dimensions of economic globalization are breaking down of national barriers, international spread of trade, financial and production activities and growing power of transnational corporations and international financial institutions in this process. (Mathur Vibha 2012) . International trade is under the influence of trends that shape the global political, cultural and economic environment. Having a complex structure International trade is constantly changing. Countries cooperate with each other in thousands of ways through international organizations, treaties, and consultations. Such cooperation generally encourages the globalization of business by eliminating restrictions on it and by precision frameworks that reduce uncertainties about what companies will and will not be allowed to do. Countries generally cooperate to gain reciprocal advantages, to attack problems they cannot solve alone, and to deal with concerns that lie outside anyone's territory. Agreements on a multiplicity of commercially related activities, such as transportation and trade, permit nations to gain reciprocal advantages. For example, groups of countries have agreed to allow foreign airlines to land in and fly over their territories, such as Canada's and Russia's agreements commencing in 2001 to allow polar over flights that will save five hours between New York and Hong Kong. Groups of countries have also agreed to protect the property of foreign-owned companies and to permit foreign-made goods and services to enter their territories with fewer precincts. In addition, countries cooperate on problems they cannot solve alone, such as by coordinating national economic programs (including interest rates) so that global economic conditions are minimally disrupted, and by restricting imports of certain products to protect endangered species. Finally, countries set agreements on how to commercially make the most of areas outside any of their territories. These include outer space (such as on the transmission of television programs), non-coastal areas of oceans and seas (such as on exploitation of minerals), and Antarctica (for example, limits on fishing within its coastal waters). World trade organisation plays an important role in promoting foreign trade by facilitating the implementation, administration and operation and furthering the objectives of the agreements and providing the framework for the implementation ,administration and operation of the plurality trade agreements. (WTO, 2016)

Every country restricts the movement across its borders of goods and services as well as of the resources, such as workers and capital, to produce them. Such restrictions make international trade burdensome; further, because the restrictions may change at any time, the ability to sustain international trade is always uncertain. However, governments today impose fewer restrictions on cross-border movements than they did a decade or two ago, allowing companies to better take advantage of international opportunities. The growth of emerging markets (e.g., India, China, Brazil, and other parts of Asia and South America especially) has impacted international trade in every way. The emerging markets have simultaneously increased the potential size and worth of current major international trade while also facilitating the emergence of a whole new generation of innovative companies. According to "A special report on innovation in emerging markets" by The Economist magazine, "The emerging world, long a source of cheap labour, now rivals the rich countries for business innovation".

Global Value Chains are high-flying feature of the international trade scenario at the present time. In fact it is an important after effect of globalisation. Intermediate goods and services from several countries are combined through integrated production networks to fabricate the final goods and services. India participates in manufacturing GVCs, inter alia, in sectors such as Chemicals, Electrical Equipment and Jewellery, in general by way of sourcing intermediates from abroad. India also has a high participation in services sectors, in particular, business services, mainly driven by the use of Indian intermediates in the exports of other countries. The share of imported inputs and intermediate goods in exports is higher in mining, textiles, machinery, and services sectors such as distribution, transport and telecom. In India, inadequate infrastructure, sub optimal connectivity with global transport networks, low transport capabilities and convoluted directorial requirements often function as major disruptive elements to participate in global value chains. In all these areas, they are at a disadvantage as compared to producers in the ASEAN countries and East Asia. India to successfully integrate into value chains - regional or global - will need to strengthen trade-related physical infrastructure, realize an suitable 
regulatory rule for transport services, improve efficiency and predictability in border procedures, undertake policy reforms in logistics services markets and reduce coordination failures. Also required is an enabling environment for industry to be able to both scale up and scale down their operations in response to demand.

The embassies provide general market as well as specific information on products and companies and acts as intermediaries between different countries The Indian embassies give much attention to the trade promotion work in addition to economic mediation. The commercial officers of the embassies formulates business meetings which forms vital part in the economic subtlety..In addition to facilitating contacts and meetings with importers, exporters, trade and industry associations they also imparts guidance about business practices and strategies.

\section{EMERGING BUSINESS MODELS IN FOREIGN TRADE}

Business models in Foreign trade may vary from industry to industry and company to company involved in the international movement of cargo. However, there are general observations on several emerging business models in the supply chain. Some of the prominent models are provided below.

\section{A. Just-In-Time System}

Just in time system is widely accepted in foreign trade especially $\mathrm{n}$ manufactured goods and here inventory is reaching a production place specifically when it is needed. Thus, a supply chain is intended to reduce problems in the flow of materials, components, and finished goods across the parties involved in the international movement of cargo. For example, it was estimated that large companies in the United States on average reduced inventory from 1.57 months in the early 1990 's to 1.36 months in 2001 . Then, it was estimated that over USD 100 billion was saved by the logistics efforts alone in the United States during the past decade (OECD, 2003a). In order for the supply chain to function, all the parties concerned need high performance in terms of punctuality, rapidity and reliability in addition to the traditional criteria of price and operating time. Also, each link of the chain needs to be harmonized, otherwise there would be little gain..

\section{B. Supply Chain Security}

The loss of cargo shipments through theft and misrouting used to be a main security element in the supply chain. In the light of increasing threats of terrorism, however, it has emerged that the mantra of the international supply chain "getting the right product to the right place at the right time" has been modified by adding "without compromising the national security"(Waduge, 2003). The whole security level of a supply chain is heavily affected by the level of security in all the parties concerned (Dulbecco and Laporte, 2003). In other words, any security effort might be in vain if a party in the supply chain fails to achieve a minimum level of security.

\section{Just-In-Case System}

Considering recent natural, political or technological disruptions to the international supply chain, the system has moved away slightly from reliance on "just-in-time" delivery to the "just-in-case" system, in which a supply chain has a certain degree of flexibility with a sound contingency plan (Waduge, 2003; Brown 2003). There is a need to consider just-in-case that it is too dangerous to rely heavily on a single source or logistics. A back-up system may be needed to mitigate uncertainty. As the just-in-case system may raise costs, it may be necessary to consider the balance between the level of security and extra costs in the supply chain.

\section{D.Outsourcing to Local Parties}

It is observed that many large companies have outsourced their production and service business to local companies. This is partly because they progressively more recognize the benefits of exploiting local companies' in-depth knowledge of local markets and Customs. In the logistics area, companies specialized in logistics activities, called third party logistics (3PL), play an important role in the international supply chain. (WCO,2004)

Based on the above dynamic developments it is relevant to analyze and forecast the foreign trade scenario of India. Hence the present study is undertaken with the following objectives.

\section{OBJECTIVES OF THE STUDY}

- To analyze the trend of Indian exports from 1999-2000 to 2015-16

- To analyze the projected values of Indian exports from 2016-17 to 2025-26.

- To analyze the post globalization trends in Indian foreign trade and emerging business models.

- To suggest measures for policy making based on the findings.

\section{MATERIALS AND METHODS}

The study is mainly done using the secondary data collected from the publications of Government of India, various journals, books and web sites. The statistical methods used are quadratic trend analysis(CAGR). Data relating to the period of 1949-1950 to 2015-2016 was used for the analysis.

\section{RESULTS AND DISCUSSION}

India is a mixed economy and is following the social democratic economic policies since 1947. From the year 1991, to keep pace with the changing trends in the market, a new liberalization policy was formulated by Dr. Manmohan Singh , the then Finance Minister of India. Due to the Economic liberalization policies in the 1990s and $2000 \mathrm{~s}$, the country steadily climbed up the economic ladder and by the year 2008 , it became the second fastest growing economy in the globe. In the process of overcoming the economic deficiencies, with the support of WTO India expected improve income and market access through liberalization and making use of 
expanding export opportunities. India has already progressively established its presence abroad in sectors such as computer software, drugs and pharmaceuticals, auto components and moving the value chain, though the export basket continues to be dominated by resource based and low technology manufactures such as textiles, gems and jewellery, leather, agro and processed food products. Globalization has brought remarkable benefits to the world in terms of trade and commerce. It has helped the countries, especially those with comparative advantage in resources. For about 40 years (195090), foreign trade of India suffered from strict bureaucratic and discretionary controls, also foreign exchange transactions were highly controlled by government and Reserve Bank of India. From independence in 1947 till mid 1990s India always faced deficit in its balance of payments, exports remained sluggish owing to lack of exportable surplus, competition in the international market, inflation at home, and increasing protectionist policies of the developed countries. World Trade Organization (WTO) lowered their forecast for world trade growth in 2015 to $2.8 \%$, from the $3.3 \%$ forecast made in April, and reduced their estimate for 2016 to $3.9 \%$ from $4.0 \%$. The projected trade growth of $3.9 \%$ in 2016 is still below the average for the last 20 years (1995-2015) of 5\%. The downward revision by WTO is due to several factors including falling import demand in China, Brazil and other emerging economies; falling prices for oil and other primary commodities; significant exchange rate fluctuations, volatility in financial markets and uncertainty regarding monetary policy of the United States. In the decade of 2000s, China accounted for half of all incremental world demand for commodities. Oil is now about \$50/barrel, one half of its rate in 2014. Commodity exporting economies are in dire straits. Brazil and Russia are in recession. Many Asian manufacturing economies are part of global value chains using China as an assembler, and have also been hard hit by China's slowdown. India has been a resilient exception since it is a net commodity importer, and is not substantially a part of world value chains. But if the world falls into recession, India may also be affected. Besides, since the global financial crisis, trade has been growing more slowly not only because world income growth is lower but also because trade itself has become much less responsive to income growth. Changes in the structure of in the trade regime, including the rise of protectionism is trade associated with the expansion or contraction of global leading to fragmentation of the global marketplace. An analysis of the export trends of India in this context can provide valuable information. The total value of export from India during the period 1999-2000 to $2015-16$ is given in Table 1 .
TABLE I:

INDIA'S TOTAL EXPORTS IN RS LAKHS FROM 1999-2000 TO 2015-16

\begin{tabular}{|c|c|c|}
\hline Year & $\begin{array}{c}\text { India's total export in Rs } \\
\text { Lakhs }\end{array}$ & $\begin{array}{c}\text { Percentage } \\
\text { change }\end{array}$ \\
\hline $1999-2000$ & 15956177.56 & \\
\hline $2000-01$ & 20357101.09 & 27.58 \\
\hline $2001-02$ & 20901797.34 & 2.68 \\
\hline $2002-03$ & 25513727.66 & 22.06 \\
\hline $2003-04$ & 29336674.75 & 14.98 \\
\hline $2004-05$ & 37533952.62 & 27.94 \\
\hline $2005-06$ & 45641786.15 & 21.60 \\
\hline $2006-07$ & 57177928.52 & 25.28 \\
\hline $2007-08$ & 65586352.18 & 14.71 \\
\hline $2008-09$ & 84075505.87 & 28.19 \\
\hline $2009-10$ & 84553364.38 & 0.57 \\
\hline $2010-11$ & 113696426.4 & 34.47 \\
\hline $2011-12$ & 146595940 & 28.94 \\
\hline $2012-13$ & 163431829 & 11.48 \\
\hline $2013-14$ & 190501108.9 & 16.56 \\
\hline $2014-15$ & 189634841.8 & -0.45 \\
\hline $2015-16$ & 171637804.6 & -9.49 \\
\hline
\end{tabular}

Source: Government of India ,2016

It is obvious from the table that the highest percentage of growth was recorded in the year 2010-11 (34.47\%) and the lowest one during 2015-16 (-9.49\%).The compound annual growth rate (CAGR) of India's total exports value from 19992000 to $2015-16$ is calculated as $14.98 \%$. India's merchandise exports reached a level of US $\$ 304.62$ billion during 2011-12 registering a growth of 21.30 percent as compared to a growth of 40.49 percent during the previous year. Despite the recent setback faced by India's export sector due to global slowdown, merchandise exports still recorded a Compound Annual Growth Rate (CAGR) of 20.3 per cent from 2004-05 to 201112. As per IMF's World Economic Outlook January, 2013, the volume of world trade (goods and services) in 2012 slowed down to 2.8 per cent compared to the 5.9 per cent achieved in 2011. As per IMF projections, growth in the volume of world trade is expected to rise to 3.8 per cent in 2013.The IMF has put its growth projections of world output at 3.5 per cent in 2013. The advanced economies are expected to grow at 1.4 per cent while the emerging and developing economies to grow at 5.5 per cent in 2013. The projected growth rates in different countries are expected to determine the markets for our exports. As per WTO's International Trade Statistics, 2012, in merchandise trade, India is the 19th largest exporter in the world with a share of 1.7 per cent and the 12th largest importer with a share of 2.5 per cent in 2011. Exports recorded a growth of 21.30 per cent during Apr-Mar 2011-12. The Government has set an export target of US \$ 360 billion for 2012-13. The merchandise exports have reached US \$ 265.95 billion in 2012-13 (Apr.-Feb.). (Department of commerce, Government of India , 2016)

The details about value of exports and imports of India are given in Table II. The table make it clear that India is always a trade deficit country during the period. 
TABLE II:

INDIA'S EXPORT AND IMPORT (IN US \$ BILLION)

\begin{tabular}{|l|l|l|l|l|l|}
\hline $\begin{array}{l}\text { Trade } \\
\text { Indicator }\end{array}$ & $\begin{array}{l}2011- \\
12\end{array}$ & $\begin{array}{l}2012- \\
13\end{array}$ & $\begin{array}{l}2013- \\
14\end{array}$ & $\begin{array}{l}2014- \\
15\end{array}$ & $\begin{array}{l}2015- \\
16\end{array}$ \\
\hline Export & 309 & 367 & 318 & 316 & 262 \\
\hline Import & 500 & 502 & 466 & 461 & 380 \\
\hline $\begin{array}{l}\text { Trade } \\
\text { deficit }\end{array}$ & -189 & -195 & -148 & -145 & -118 \\
\hline
\end{tabular}

Source: DGFT , RBI Statistics

Trade balance during 2011-12 is US $\$-189$ billion and it turns to be US $\$-118$ billion, attributed to US $\$ 262$ billion export and US \$ 380 billion import. If a domestic company manufactures a lot of its products in other countries or if the raw materials are shipped overseas to its plant, trade deficit arises. It raises the standard of living of a country's residents for a short period of time, since they now have access to a wider variety of goods and services for a more competitive price. It can reduce the threat of inflation, since the products are priced lower. A trade deficit can also indicate that the country's residents are feeling confident, and wealthy, for a short period of time enough to buy more than the country produces. (Kimberly Amdeo,2016). In terms of the stock market, a prolonged trade deficit could have adverse effects. If a country has been importing more goods than it is exporting for a sustained period of time, it is essentially going into debt (much like a household would). Over time, investors will notice the decline in spending on domestically produced goods, which will hurt domestic producers and their stock prices. Given enough time, investors will realize fewer investment opportunities domestically and begin to invest in foreign stock markets, as prospects in these markets will be much better. This will lower demand in the domestic stock market and cause that market to decline. (Kario Paul A Brown et al, 2016) . An analysis of trade balance of India from 194950 to 2012-13 reveals that the trade deficit was about Rs 132 crores in 1949-50 and in 1995-96 it increases to Rs. 16325 crores and after that it steadily increased and reached Rs 801083 crores during 2012-13. The details of the same are depicted in Figure 1.

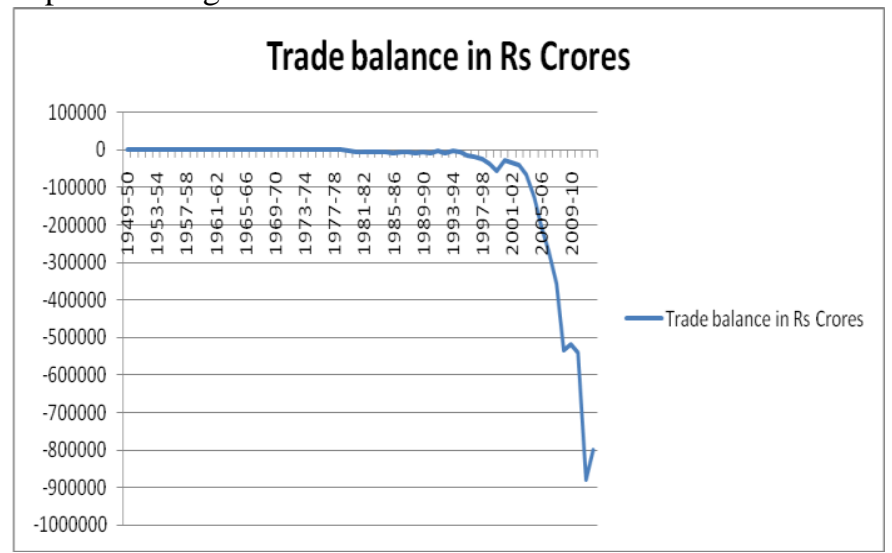

Fig :1 Trade balance from 1949-50 to 2012-13

Source: Government of India , 2016
An analysis of compound annual growth rate (CAGR) is often helpful to get a comparative view about exports and imports during different time periods. CAGR of Indian exports and imports during 6 decades from 1949-50 to 2009-10 is provided in Table 3.

TABLE III:

COMPOUND ANNUAL GROWTH RATE(CAGR) OF INDIAN EXPORTS

\begin{tabular}{|c|c|c|c|}
\multicolumn{5}{|c}{ AND IMPORTS } \\
\cline { 3 - 4 } S1.No & Time period & CAGR & \\
\hline 1 & & Exports & Imports \\
\hline 2 & $1949-50$ to $1959-60$ & 2.8 & 1.55 \\
\hline 3 & $1959-6$ o to $1969-70$ & 8.2 & 5.07 \\
\hline 4 & $1969-70$ to $1979-80$ & 16.33 & 19.15 \\
\hline 5 & $1979-80$ to $1989-90$ & 15.73 & 3.86 \\
\hline 6 & $1989-90$ to $1999-00$ & 19.13 & 19.8 \\
\hline
\end{tabular}

Source : Estimated

Pre liberalization period characterizes by slow growth rate of exports where as post globalization period shows a rapid growth rate. There was a marked decrease in the CAGR of imports from 1979-80 to 1989-90 (3.86). The projected values of Indian exports are calculated using quadratic trend analysis and is provided in Table 4.

TABLE IV:

PROJECTED VALUES OF INDIAN EXPORTS FROM 2016-17

\begin{tabular}{|c|c|c|}
\hline Year & India's total export in Rs Lakhs & Percentage Change \\
\hline $2016-17$ & 194974595.1 & - \\
\hline $2017-18$ & 207082018.6 & 6.21 \\
\hline $2018-19$ & 219189442.1 & 5.85 \\
\hline $2019-20$ & 231296865.6 & 5.52 \\
\hline $2020-21$ & 243404289.1 & 5.23 \\
\hline $2021-22$ & 255511712.6 & 4.97 \\
\hline $2022-23$ & 267619136.2 & 4.74 \\
\hline $2023-24$ & 279726559.7 & 4.52 \\
\hline $2024-25$ & 291833983.2 & 4.33 \\
\hline $2025-26$ & 303941406.7 & 4.15 \\
\hline
\end{tabular}

Source: Estimated

The projected values of exports show an increasing trend and the compound annual growth rate(CAGR) is 4.55.

\section{CONCLUSION}

In IMF's World Economic Outlook (January 19, 2016) India and the rest of emerging Asia are generally projected to continue growing at a robust pace. As per Economic Survey 2015-16, the projected growth rate of GDP for the year 201516 is likely to be between 7\% to 7.6\%. During 2012-13 India's exports accounts for Rs.163431829 Lakhs which increases to Rs.171637804.6 Lakhs during 2015-16. From the analysis it is found that value of exports increases from Rs.194974595.1 Lakhs in 2016-17 to Rs. 303941406.7 Lakhs in 2025-26. Eventhough the rate of increase is not rapid India has a rich prospectus in the foreign trade landscape. Globalisation characterized by openness ,adaptation and responsiveness paved way to newer dimensions of Indian foreign trade. 


\section{REFERENCES}

[1] Ministry of Commerce, Government of India, Annual Reports

[2] Amadeo Kimberly, 2016,Trade deficit, definition, causes, effects, Role in BOP, www.thebalance.com accessed on 28/12/2016.

[3] Dulbecco, Philippe and Laporte, Bertrand, 2003, "How can the security of the international supply chain be financed - A Global public good approach", Center of Study and Research on International Development, April 2003, Clermont Ferrand (France).

[4] Kario Paul A Brown et al, 2016, Trade deficit and effects on stock market, www.investopedia.com accessed on 28/12/2016

[5] Tushar K Mishra ,1992,India's foreign trade :Lessons and Challenges, Indian Journal of Asian Affairs, Vol 5, No 1/2,PP -20-36

[6] Mathur Vibha , 2012,Foreign Trade,Export Import Policy and Regional Trade Agreements of India, New Century Publications, New Delhi.

[7] OECD, 2003a, "Security in Maritime Transport: Risk Factors and Economic Impact", DSTI/DOT/MTC(2003)47/FINAL, 4 September 2003, Paris.

[8] Waduge, Shenali, 2003, "Emerging trends in global logistics", Financial Times, London 